\title{
A top predator forages low on species-rich tropical food chains
}

\author{
Timothy D. Jardine $e^{1,2,3}$ \\ ${ }^{1}$ Australian Rivers Institute, Griffith University, Nathan, Queensland 4111, Australia \\ ${ }^{2}$ School of Environment and Sustainability, University of Saskatchewan, Saskatoon, Saskatchewan, Canada S7N 5B3
}

\begin{abstract}
Emergent properties of food webs, including food-chain length (FCL), may differ across latitudinal gradients because of strong differences in biodiversity and productivity between warm and cold regions. Theory predicts long food chains in the tropics because of high species richness and productivity, but empirical data suggest otherwise. Here I show that an opportunistic top predator common to coastal rivers and streams, the Australian Longfinned Eel (Anguilla reinhardtii), feeds $\sim 1$ trophic position higher in temperate systems $(4.7 \pm$ $0.3[\mathrm{SD}])$ than in tropical systems $(3.8 \pm 0.5)$. This result suggests shorter food chains that contain a diverse array of large-bodied herbivores and omnivores that act as prey for generalist predators, such as eels, in tropical systems. The resulting altered size spectrum limits the size and trophic position of top predators that can be supported in the face of constraints from known limits to FCL, including productivity, ecosystem size, and disturbance. This framework has general application for food webs and suggests unique structural and functional attributes of highly threatened tropical freshwater ecosystems.
\end{abstract}

Key words: stable isotopes, trophic position, Australian Longfinned Eels, Anguilla reinhardtii, streams, latitude, Roman-nosed Goby, Awaous acritosus, food chain length

The length of the food chain is a fundamental property of ecosystems that influences species interactions, material cycling, and contaminant concentrations in top predators (Carpenter et al. 1985, Hairston and Hairston 1993, Kidd et al. 1995). Understanding the broad-scale patterns and controls on food-chain length (FCL) can yield insights into ecosystem response to disturbance (Power et al. 2008), the probable effects of invasive species (Woodward and Hildrew 2001), and the interaction between biodiversity and ecosystem function (Duffy et al. 2005). As such, FCL is an often studied and controversial topic in ecology (Post 2002).

Previous empirical and modeling studies have yielded 2 contradictory hypotheses regarding FCL along latitudinal gradients that are known to vary in species diversity and productivity. Productivity hypotheses predict shorter food chains in resource-limited systems because of energy inefficiencies during trophic transfer (Oksanen et al. 1981). According to these hypotheses, food chains in tropical freshwaters should be longer than those in comparable temperate systems because the former are more productive than the latter (Gross et al. 1988, Davies et al. 2008). Also, species richness tends to be higher in the tropics (Willig et al. 2003). Thus, ecosystems in this region should support longer food chains through the progressive addition of top predators (Cohen and Newman 1991, Post and Taki- moto 2007). Despite these theoretical predictions, a counter hypothesis arises from empirical observations in the tropics, where short food chains have been observed (Lewis et al. 2001, Jepsen and Winemiller 2002). This pattern is attributed to considerable omnivory and the presence of largebodied herbivorous and detritivorous fish (Winemiller 1990) that serve as prey for top predators (Layman et al. 2005). These observations would suggest that tropical food chains will be shorter than temperate food chains because temperate systems have more discrete, linear food chains with small-bodied, herbivorous insects and more size-structured predator-prey interactions (France et al. 1998, Jennings and Warr 2003).

One of the difficulties in testing for differences in FCL among latitudes lies in the variation in species composition and ecosystem types that occur across the gradient. This variation combined with the influence of other factors, such as ecosystem size and disturbance (Post et al. 2000, McHugh et al. 2010, Sabo et al. 2010) and their interaction with productivity (Schoener 1989), may explain why meta-analyses examining latitudinal effects on FCL have been equivocal (Vander Zanden and Fetzer 2007). One solution to this problem is to examine the trophic position of a single top predator that occurs across a broad latitudinal gradient while holding other factors, such as ecosystem

E-mail: ${ }^{3}$ tim.jardine@usask.ca

DOI: 10.1086/685858. Received 31 December 2014; Accepted 18 August 2015; Published online 15 February 2016.

Freshwater Science. 2016. 35(2):666-675. @ 2016 by The Society for Freshwater Science. 
size, as constant as possible. This single-species solution limits inferences about maximum FCL because the identity of the top predator can vary among locations (McHugh et al. 2010, Warfe et al. 2013), but it provides insights into how top predators respond to available prey representing different energy pathways and provides a reasonable approximation of maximum FCL (Tunney et al. 2012).

Catadromous anguillid eels (Anguilla spp.) occur throughout coastal rivers and streams of the mid latitudes and, therefore, can serve as a model species for testing the effects of latitude on predator trophic position. They range over $\sim 50$ to $60^{\circ}$ of latitude (e.g., Anguilla anguilla: $75^{\circ} \mathrm{N}-$ $8^{\circ} \mathrm{N}$, Anguilla rostrata: $66^{\circ} \mathrm{N}-7^{\circ} \mathrm{N}$, Anguilla bicolor bicolor: $22^{\circ} \mathrm{N}-27^{\circ} \mathrm{S}$; Froese and Pauly 2012) and recruit to rivers as elvers after following prevailing currents from their spawning grounds in the open ocean. After ascending rivers, they feed and grow in freshwater for as long as $40 \mathrm{y}$ before making a one-way trip back to sea to spawn and die. In river and stream food webs they act as top predators, feeding on a generalist diet of invertebrates and fishes with some evidence of an increase in fish prey with increasing body size (Pusey et al. 2004).

I used a single species of anguillid eel, the Australian Longfinned Eel (LFE; Anguilla reinhardtii) to test contrasting theoretical and empirically based predictions regarding toppredator trophic position in tropical and temperate systems. I collected LFEs from 4 regions that spanned the latitudinal range of the species, with tropical North Queensland at the northern extreme and the temperate island of Tasmania at the southern extreme. I measured their stable $\mathrm{N}$ isotopes and standardized them to a baseline value to calculate trophic position. These measurements allowed direct comparisons of a fundamental foodweb property across a latitudinal gradient and have implications for models of ecosystem structure and function.

\section{METHODS}

I collected samples across a latitudinal gradient in eastern Australia during the years 2010-2011 in 4 regions (Fig. 1): 1) tropical north Queensland north of Cairns, $\sim 16^{\circ} \mathrm{S}$; 2) subtropical southeast Queensland south of Brisbane, $\sim 28^{\circ} \mathrm{S}$; 3) temperate mainland Victoria east of Melbourne, $\sim 38^{\circ} \mathrm{S}$; and 4) temperate island Tasmania northeast of Hobart, $\sim 42^{\circ} \mathrm{S}$. Sites were $2^{\text {nd }}$ - to $5^{\text {th }}$-order wadeable streams with upstream drainage areas that ranged from 9 to $2100 \mathrm{~km}^{2}$ (described by Jardine 2014). They generally had forested riparian zones and were directly connected to the sea (as evidenced by the presence of LFEs) with few in-stream structures and limited agricultural and urban development. A suite of limnological measurements made at each site suggested that most sites in all regions were clear, circumneutral, oligotrophic, and well oxygenated (Jardine 2014).

All sites were flowing at the time of sampling. They were ungauged, but most streams were situated in clusters of streams with flow-regime classes 3 to 7 (Kennard et al. 2010), characterized by few or no 0 -flow days with limited flashiness (rates of rise and fall). Hydrological disturbance is unlikely to have varied systematically across the study range, but because I did not measure disturbance directly (e.g., by means of Pfankuch scores of channel morphology; McHugh et al. 2010), disturbance history is a factor that was unaccounted for in the analyses. Ecosystem size differed slightly among the regions. Temperate mainland sites had significantly larger upstream catchment areas than did the other regions (Jardine 2014). Upstream catchment area can over- or underestimate ecosystem size (aquatic habitat) because of regional differences in rainfall and varying inputs from groundwater (McHugh et al. 2010), but it is correlated with cross-sectional area (Sabo et al. 2010) and, therefore, it provides a reasonable estimation of cross-sectional area. I estimated \% canopy cover as a $2^{\text {nd }}$ measure of ecosystem size (Jardine 2014) because canopy cover declines with increasing stream width in these forested coastal streams. Productivity affects FCL, so I used 2 proxy measures of productivity, benthic chlorophyll $a$ and invertebrate standing biomass, at each site (Takimoto and Post 2013). Benthic chlorophyll $a$ provides a coarse estimate of primary productivity of stream periphyton (Morin et al. 1999), and invertebrate biomass has been used as a surrogate to represent resource availability (McHugh et al. 2010).

I collected samples for biofilm stable isotope analysis (SIA) and chlorophyll $a$ analysis by scrubbing a minimum of 3 rocks at each of 3 locations in the stream. I used a Surber sampler to collect benthic invertebrates from 3 locations that captured the dominant habitats (riffles and pools) and substrates at each site. These 3 replicates were pooled into a single sample that was frozen for biomass estimation and SIA.

I collected LFEs at 27 of the 50 sites sampled (northern Queensland: $n=7$ sites, southeastern Queensland: $n=6$ sites, Victoria: $n=8$ sites, Tasmania: $n=6$ sites). Sample sizes ranged from $n=1$ to $n=10$ individuals/site. I used either a Smith-Root LR-24 backpack electrofisher (tropical, subtropical, and temperate island sites) or a Smith-Root 7.5 GPP bank-mounted electrofisher (temperate mainland sites) (Smith-Root, Vancouver, Washington) in representative habitats and areas known to contain LFEs (i.e., deeper pools with woody debris and other vegetation). Fish community data for each site at the time of sampling are unavailable, but species richness declines from north to south in Australia. Thirty-nine species are known to occur in streams and rivers in northern Queensland, 28 in southeastern Queensland, 13 in Victoria, and only 8 in Tasmania (Unmack 2001).

To avoid the confounding effect of recent freshwater arrival on isotope ratios and to enable nonlethal removal of fin tissue (Jardine et al. 2011), I sampled only individuals $>200 \mathrm{~mm}$. LFEs arrive in freshwater at a total length of $\sim 50 \mathrm{~mm}$ (Shiao et al. 2002), so this $>4 \times$ increase in size 


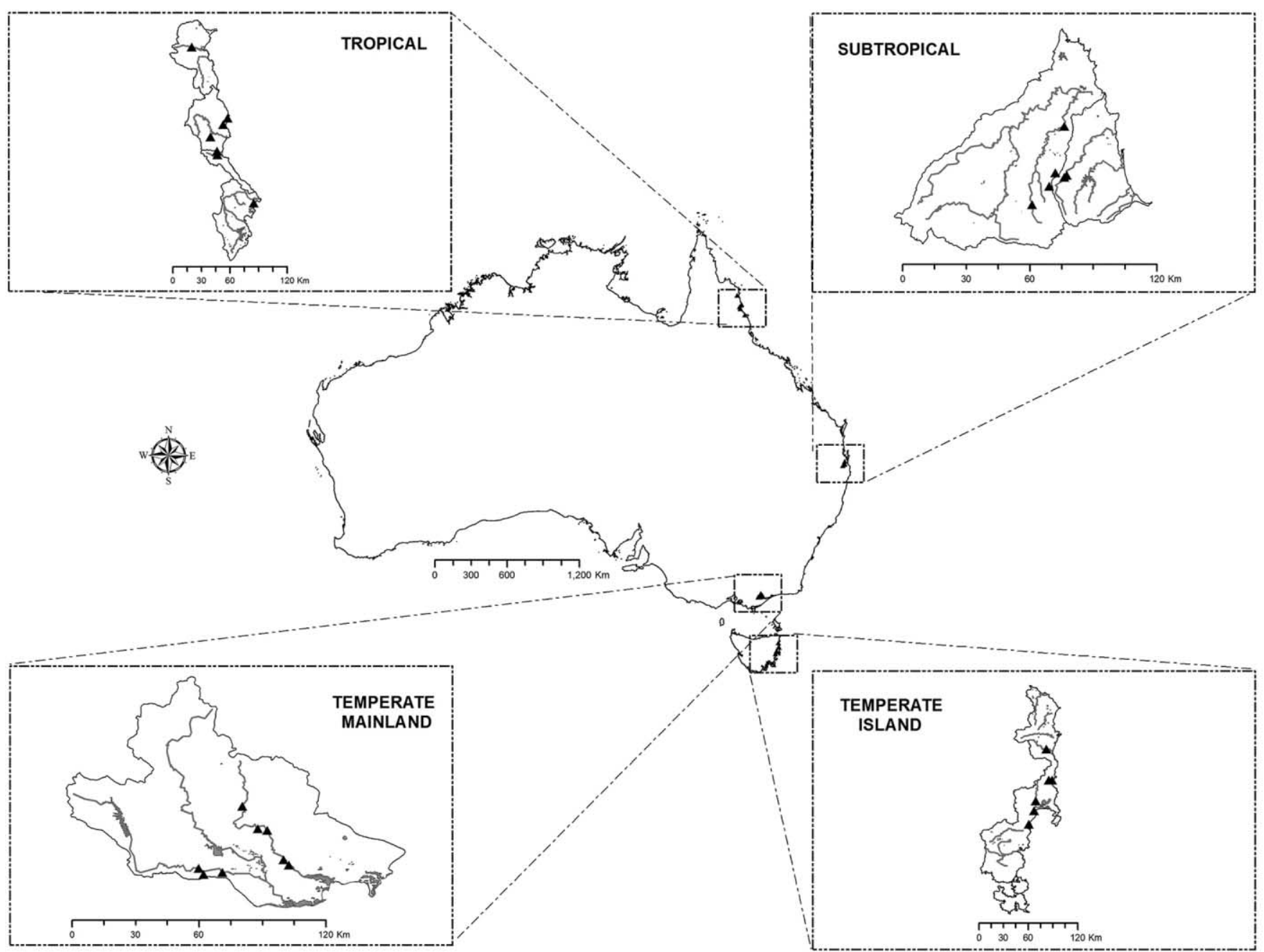

Figure 1. Streams sampled in 4 regions (tropical, subtropical, temperate mainland, temperate island) along a latitudinal gradient in eastern Australia.

would be sufficient to dilute any residual marine isotope signal and to ensure that isotopic signatures would represent diet obtained while LFEs were in freshwater. I anesthetized LFEs, removed fin tissue, measured total length, placed the tissue in a clean vial, and froze it.

At the laboratory, I pipetted biofilm samples into glass vials and allowed excess water to evaporate in a drying oven before homogenizing dry samples with a mortar and pestle or glass stirring rod. I sorted invertebrates to family and tamped them dry on laboratory towels (Kimwipe ${ }^{\circledR}$; KimberlyClark, Roswell, Georgia). I placed them in preweighed vials and weighed them before and after drying in the oven to obtain wet and dry mass. I dried and homogenized samples as described above for the biofilm. I placed $\sim 3 \mathrm{mg}$ of dried, ground biofilm and $1 \mathrm{mg}$ of invertebrate samples in $\mathrm{Sn}$ capsules for SIA. I also dried fin tissue, cut it to appropriate mass $(\sim 1 \mathrm{mg})$, and placed tissue in Sn capsules for SIA. Samples were analyzed for stable isotope ratios at 2 labora- tories as described previously (Jardine 2014). In-house standards had standard deviations (SD) that ranged from 0.1 to $0.3 \%$.

I calculated LFE trophic position (TP) according to standard isotopic methods (McHugh et al. 2010, Sabo et al. 2010) using the formula:

$$
\mathrm{TP}=\left(\delta^{15} \mathrm{~N}_{\mathrm{LFE}}-\delta^{15} \mathrm{~N}_{\text {baseline }}\right) / \Delta^{15} \mathrm{~N}+2
$$

where $\delta^{15} \mathrm{~N}_{\text {LFE }}$ was the $\delta^{15} \mathrm{~N}$ of LFEs, $\delta^{15} \mathrm{~N}_{\text {baseline }}$ was the $\delta^{15} \mathrm{~N}$ of invertebrate primary consumers (TP $=2$ ), and $\Delta^{15} \mathrm{~N}$ is diet-tissue ${ }^{15} \mathrm{~N}$ fractionation. I used a value of $2.5 \%$ for $\Delta^{15} \mathrm{~N}$ (Vanderklift and Ponsard 2003). Invertebrate primary consumers (according to Gooderham and Tsyrlin 2002) consisted of various combinations of Leptophlebiidae, Psephenidae, Baetidae, Caenidae, Elmidae, Gripopterygidae, Pyralidae, Oligochaeta, Simuliidae, Tipulidae, Scirtidae, Corbiculidae, Calocidae, Gastropoda, and Notonemouridae (Jardine 2014). 
All other invertebrates were predators (according to Gooderham and Tsyrlin 2002).

I screened all data for nonnormality and heteroscedasticity by examining probability plots. I used an analysis of covariance (ANCOVA) with region as the fixed factor and body length as the covariate to test whether LFEs had different TPs in the 4 regions. All sites were indexed to a $\delta^{15} \mathrm{~N}$ baseline, so I pooled individuals from all sites within regions for this analysis. I assessed where in the food chain changes in TPs occurred among systems by calculating the difference in $\delta^{15} \mathrm{~N}$ between primary consumers and biofilm, between invertebrate predators and primary consumers, and between LFEs and predators at all sites where paired data were available. I used an analysis of variance (ANOVA) to compare these differences among regions. To assess other known drivers of variation in mean LFE TP, I used a general linear model (GLM) ANOVA with region as a fixed factor, LFE body size, and indicators of ecosystem size (upstream catchment area and \% canopy cover) and productivity (benthic chlorophyll $a$ and invertebrate biomass per unit area) as covariates. I set $\alpha=0.05$.

\section{RESULTS}

The range of baseline $\mathrm{N}$ isotope ratios in the study streams was high but did not vary systematically among regions. $\delta^{15} \mathrm{~N}_{\text {baseline }}$ ranged from $0.3 \%$ in the Avon River, Victoria (Avon-Turton track), to 8.3\% in Freshwater Creek, northern Queensland. One site (Endeavour River) had higher $\delta^{15} \mathrm{~N}_{\text {baseline }}$ compared to $\delta^{15} \mathrm{~N}$ in predators and was excluded from the analysis. At all other sites, $\delta^{15} \mathrm{~N}$ of predators was higher than $\delta^{15} \mathrm{~N}_{\text {baseline, }}$ a result supporting the use of primary consumers to represent TP $=2 . \delta^{15} \mathrm{~N}_{\text {baseline }}$ did not differ among regions $\left(F_{3,38}=0.736, p=0.537\right)$, indicating random variation in baseline values across the study area.

LFE TPs differed among body sizes and regions (Fig. 2). The mean TP of LFEs within sites ranged from a low of 2.6 in Freshwater Creek, northern Queensland, to a high of 5.3 in the Buxton River, Tasmania, and increased between tropical and temperate locations. Mean LFE TP was $3.8 \pm$ 0.5 (SD) at tropical sites, $3.9 \pm 0.3$ at subtropical sites, $4.4 \pm$ 0.5 at temperate mainland sites, and $4.7 \pm 0.3$ at streams on the temperate island. The smallest LFE sampled was $220 \mathrm{~mm}$ at the Douglas River upstream site in Tasmania, and the largest was $1200 \mathrm{~mm}$ at Thompson Creek in northern Queensland. Within-region regressions between length and TP were generally weak $\left(r^{2}=0.05,0.16,0.05\right.$, and 0.19 for tropical, subtropical, temperate mainland, and temperate island, respectively), but size was a significant predictor of TP in the model $\left(F_{1,115}=9.88, p=0.002\right)$. Marginal means differed among the regions $\left(F_{3,115}=35.26, p<0.001\right)$. All regions differed $(p<0.05)$ except tropical and subtropical $(p=0.239)$. For a given body size, LFEs had highest TPs at the temperate island sites, followed by temperate mainland sites, and lowest TPs at subtropical and tropical sites.

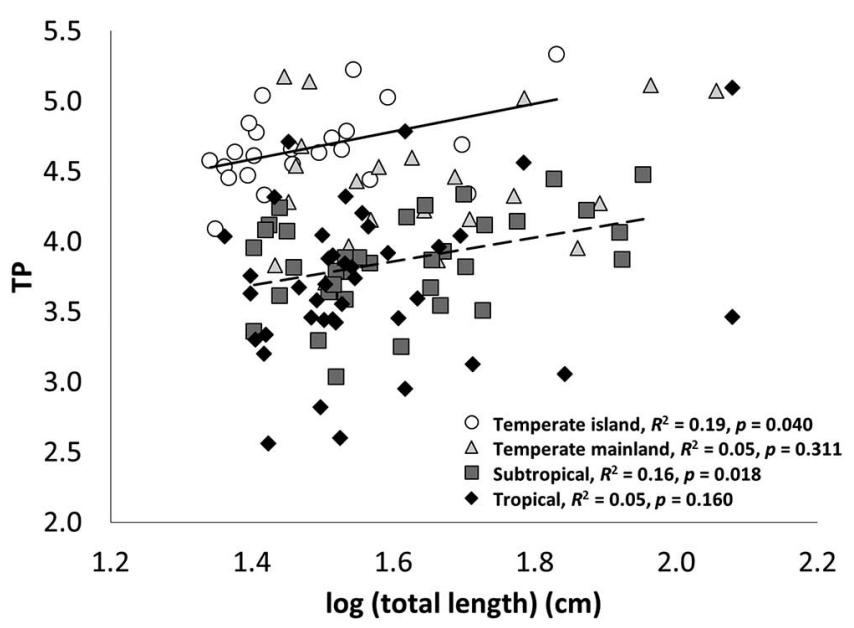

Figure 2. Trophic position (TP; derived from $\delta^{15} \mathrm{~N}$ ) vs body size of stream-dwelling Longfinned Eels (Anguilla reinhardtii) in 4 regions (tropical, subtropical, temperate mainland, temperate island) along a latitudinal gradient in eastern Australia. Best fit lines are shown for significant within-region regressions.

Differences in LFE TPs among regions were driven by patterns high in the food chain. The changes in $\delta^{15} \mathrm{~N}$ from biofilm to primary consumers $\left(F_{3,37}=0.681, p=0.886\right)$ or from primary consumers to predators $\left(F_{3,20}=0.933, p=\right.$ 0.443 ) (Fig. 3) did not differ among regions. However, the change in $\delta^{15} \mathrm{~N}$ from predators to LFEs did differ significantly among regions $\left(F_{2,14}=13.540, p=0.001\right.$; Fig. 3$)$. Predators were rare in the temperate island region and thus the predator-LFE pairing could not be tested.

A full model that included all 5 explanatory variables (region, mean body size, upstream drainage area, invertebrate biomass, and chlorophyll $a$ biomass) accounted for a large amount of variation in LFE TP. Too few invertebrates for biomass estimation at 1 temperate island site and the exclusion of the Endeavour River site in the tropics reduced sample size in those regions to 5 sites each. The full model was significant $\left(F_{8,15}=7.798, p<0.001\right)$ as were the region $\left(F_{3,15}=12.692, p<0.001\right)$ and catchment area $\left(F_{1,15}=4.470\right.$, $p=0.052)$ terms. The catchment area term had a negative coefficient, indicating lower LFE TP at larger sites within regions (Fig. 4A). Neither \% canopy $\left(F_{1,15}=0.453, p=0.511\right)$, benthic chlorophyll $a\left(F_{1,15}=1.784, p=0.202\right.$; Fig. 4B), benthic invertebrate biomass $\left(F_{1,15}=2.496, p=0.135\right.$; Fig. $\left.4 C\right)$, nor mean LFE body size $\left(F_{1,15}=1.776, p=0.203\right)$ was significant in the model.

\section{DISCUSSION}

LFEs fed $\sim 1$ TP higher in temperate food chains than in tropical food chains. This result implies that despite a theoretical basis for longer food chains in productive systems and empirical evidence to support that hypothesis within a given biogeographic region (Takimoto and Post 2013), regional differences in species composition probably over- 


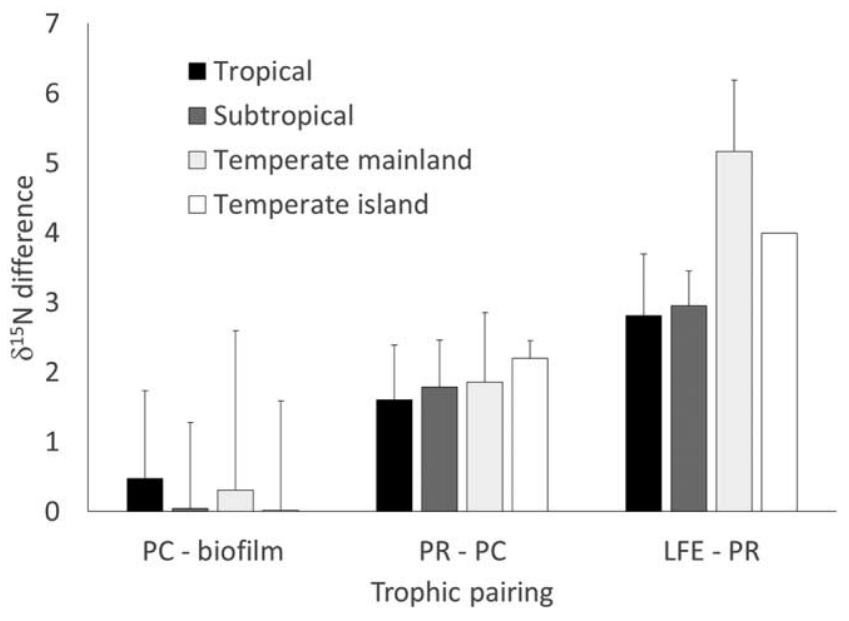

Figure 3. Mean (+1 SD) difference in $\delta^{15} \mathrm{~N}$ between adjacent trophic positions in streams in 4 regions (tropical, subtropical, temperate mainland, temperate island) along a latitudinal gradient in eastern Australia (biofilm to invertebrate primary consumer [PC]; PC to predatory invertebrates [PR]; PR to Longfinned Eels [LFE]).

whelm local effects. My results lend support to the view that fish feed on short, productive food chains in tropical freshwaters (Layman et al. 2005). These systems exhibit high rates of primary and secondary production (Gross et al. 1988, Davies et al. 2008), and high secondary production is driven mainly by large-bodied, noninsect taxa, such as prawns, shrimps, and anurans (Jacobsen et al. 2008) that feed low on the food chain (Burns and Walker 2000, Jardine 2014).

Other factors that accounted for variation in LFE TP included body size and ecosystem size. Larger LFEs had higher TPs, but the effect was weak and did not explain variation among sites, results consistent with an opportunistic diet across the life span of this species (Pusey et al. 2004). Ecosystem size had a negative coefficient in the overall model because larger streams in each ecosystem had LFEs with lower TPs within each region. This result is counter to empirical observations that longer food chains are associated with larger ecosystems (Takimoto and Post 2013) because of attenuation of hydrological disturbance in larger basins (Sabo et al. 2010). However, Warfe et al. (2013) showed that Australian streams do not exhibit this hydrological behavior. Instead, small and large systems have the highest disturbance from both low and high flow. Thus, other factors, such as a greater forage base in larger streams that includes large-bodied crustaceans, may have decreased LFE TP in each region and produced this counter-intuitive result. Furthermore, lower LFE TP in tropical waters and larger streams could have been a consequence of stronger disturbance regimes at those locations (McHugh et al. 2010), but I did not quantify disturbance history. A more comprehensive geomorphological assessment of channel stability including degradation, aggradation, overwidening, or change in planform would characterize reaches as adjusting or in equilibrium (Sullivan et al. 2006) and might aid in understanding the role of disturbance in affecting resources and subsequent TP of LFEs.
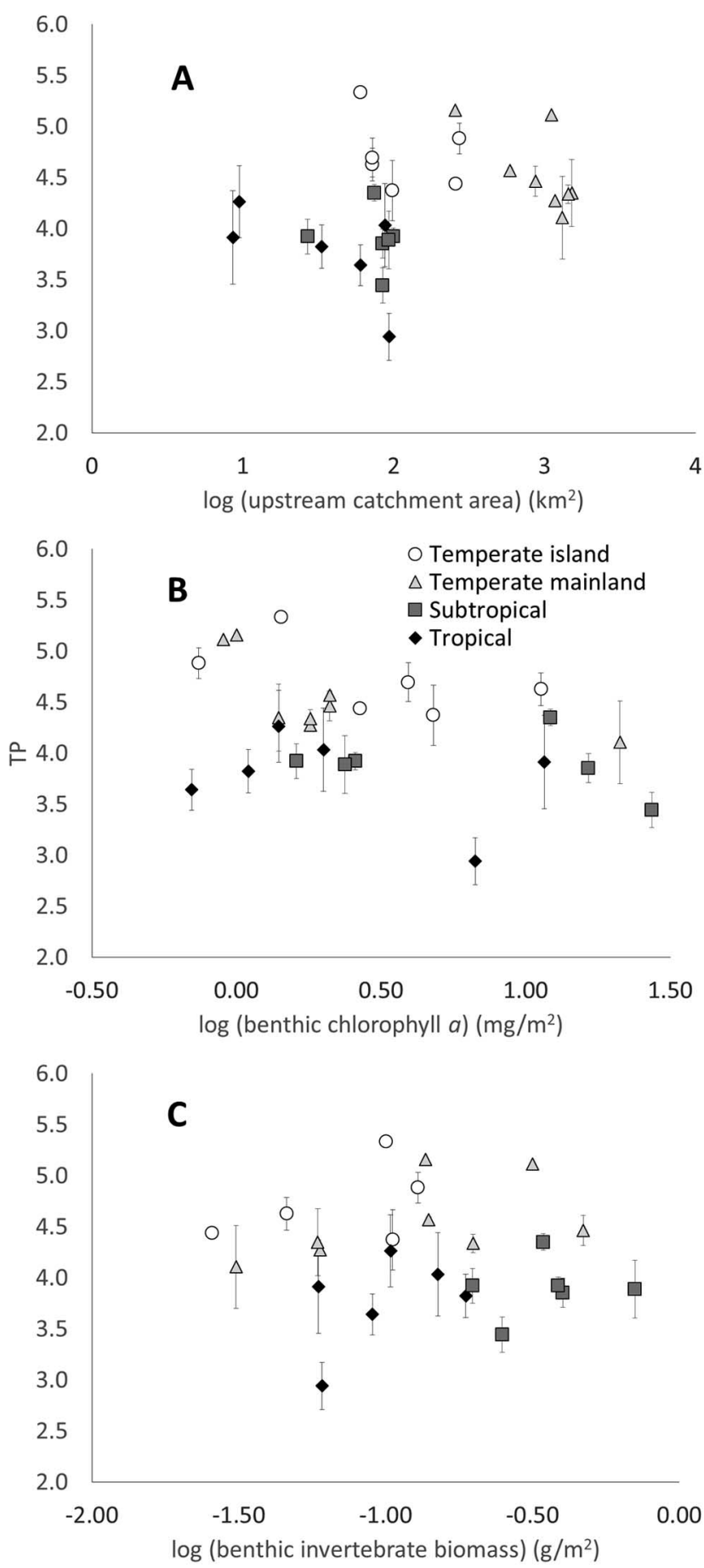

Figure 4. Mean $( \pm 1$ SD) trophic position (TP) of Longfinned Eels vs ecosystem size (upstream catchment area) (A), benthic chlorophyll $a$ (B), and benthic invertebrate biomass (C) in streams along a latitudinal gradient in eastern Australia. 
LFEs fed lower on the food chain in regions where species richness is higher. Rivers in tropical and subtropical Queensland contain $>25$ fish species, whereas rivers in temperate Victoria and Tasmania support $<15$ fish species (Unmack 2001). Effects of ecosystem size on FCL (e.g., Post et al. 2000) are mediated through fundamental relationships between ecosystem size and species richness (Cohen and Newman 1991), with the expectation that the addition of species will increase maximum FCL (Post and Takimoto 2007). Thus, my finding of lower LFE TPs in species-rich tropical webs, assuming they represent FCL reasonably (Tunney et al. 2012), is at odds with theoretical expectations. Greater speciation may occur in trophic guilds able to maximize growth by feeding low on the food chain in the productive tropics rather than in the top predator guild (Gross et al. 1988, Novotny et al. 2006). Fish species that fit this description include the diverse Loricariid catfishes and Procolodontids in the Neotropics (Taylor et al. 2006, Lujan et al. 2011) and cichlids in Africa (Wagner et al. 2009). Specialization or resource partitioning occurs most often at low trophic levels (Schoener 1974, Behmer and Joern 2008) largely because plants and insects have greater taxonomic and functional diversity than do fish, birds, and mammals, which most often have the role of top predator in food webs (Sergio et al. 2008).

Contradictions between theoretical predictions and empirical observations can be reconciled by examining LFE trophic position in the context of predator-prey body sizes (Jennings and Warr 2003, Hoeinghaus et al. 2008, Riede et al. 2011). Slopes of regressions of body mass against TP are relatively consistent, particularly among ectothermic vertebrates (Riede et al. 2011; see Fig. 2 showing the inverse relationship for LFEs as an example). Thus, we can assume a log-linear increase in size with TP for all species in all regions (Fig. 5). Larger organisms are more vulnerable to disturbance and habitat shrinkage (McKinney 1997). Therefore, larger animals will be excluded from small, unproductive, or disturbed habitats (Burness et al. 2001), thereby shortening food chains in all regions (Post et al. 2000, McHugh et al. 2010, Sabo et al. 2010, Takimoto and Post 2013). However, the presence of large-bodied herbivores and omnivores in warmer aquatic systems alters body-sizeTP relationships and introduces scatter into the relationship (Fig. 5; Layman et al. 2005, Hoeinghaus et al. 2008, Riede et al. 2011). These organisms, which include fishes (Winemiller 1990) and crustaceans (Jardine 2014), have maximized body size while feeding on a diet largely consisting of algal, plant, and detrital material (Hoeinghaus et al. 2008), effectively short-circuiting the body-size vs TP equation and setting a new baseline for further increase in size along food chains (Fig. 5). As a result, for a given ecosystem size, productivity, and level of disturbance, tropical webs will necessarily have shorter mean FCLs because the sum of all energy pathways to top predators results in body size reaching a maximum at a lower TP. The prevalence of these her-

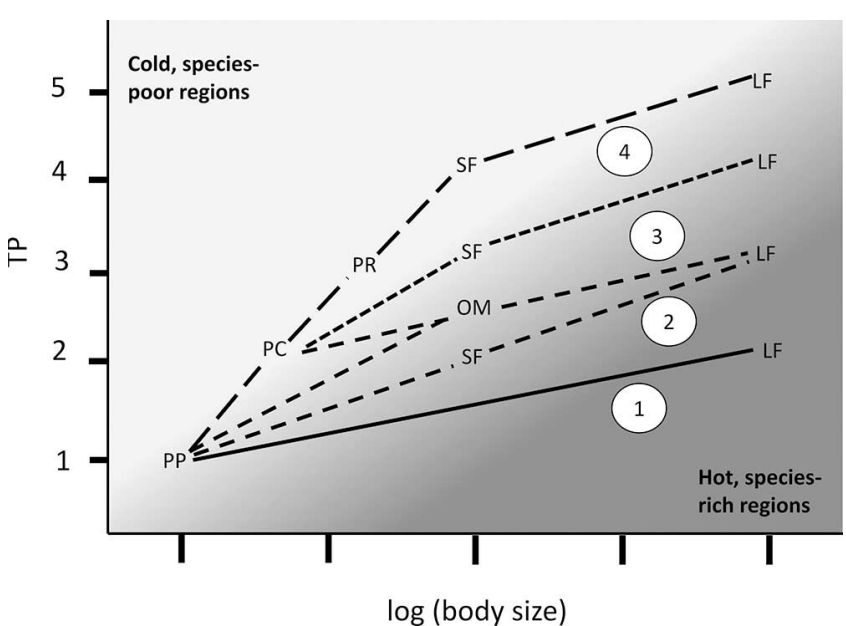

Figure 5. Simplified diagram depicting representative energy pathways in freshwater food webs, with increases in body size at each trophic position (TP) (Riede et al. 2011) for primary producers (PP) to small insects and zooplankton (PC), large insects and zooplankton (PR), large-bodied omnivorous prawns, crayfish and shrimp (OM), small fish (SF), and large fish (LF). Loss or exclusion of large top predators from unproductive, disturbed, or small ecosystems results in shorter chains at all latitudes (Takimoto and Post 2013), but when those factors are held constant, food-chain length (terminating at large fish) differs among latitudes as indicated by shading. Major foodweb pathways range from those dominated by large-bodied fish herbivores $(1=$ direct links between PP and LF; Layman et al. 2005), small herbivorous fishes (2; Winemiller 1990), and omnivorous crustaceans (3; Jardine 2014) as prey for large fish in hot, species-rich ecosystems (Hoeinghaus et al. 2008) to insect- and zooplankton-dominated webs in cold, species-poor ecosystems (4; Vander Zanden and Rasmussen 1996, France et al. 1998). Mean FCL is dictated by the relative proportion of energy pathways (solid and hatched lines) leading to large fish.

bivorous and omnivorous crustaceans and fishes is in essence a community-organization or design constraint (Pimm 2002, Post 2002), but one that is testable-food webs that contain large-bodied taxa known to feed low on the food chain should always exhibit shorter mean FCL than food chains that do not (Hoeinghaus et al. 2008).

The main mechanism for lower TPs of predators in tropical regions is the high prevalence of herbivorous and omnivorous fishes (Layman et al. 2005), a common feature of tropical webs (Gonzalez-Bergonzoni et al. 2012). Many functional traits of fish assemblages change comparably from up- to downstream in tropical and temperate rivers, but the relative lack of herbivores is a common feature of temperate food webs (Ibanez et al. 2009). Exceptions, such as Gizzard Shad (Dorosoma cepedianum) and Central Stonerollers (Campostoma anomalum), exist in warmer temperate regions, such as southern North America, but in coldwater webs herbivore niches are occupied almost exclusively by insects that are preyed upon by in- 
vertebrates. These predator-prey relationships exhibit shallow body-size vs TP slopes (i.e., smaller organisms attain higher TPs; Riede et al. 2011, Jardine 2014). A higher proportion of herbivores and omnivores in tropical webs also is found in eastern Australia, where consumption of algae, macrophytes, and detritus is virtually absent in the fish communities of the southern mainland and Tasmania $(<5 \%)$, but relatively common in southeastern and northern Queensland (>20\%) (Pusey et al. 2011). Several algivorous and detritivorous species including Bony Bream (Nematalosa erebi) and Mullet (Liza spp.) are found only at northern latitudes.

Herbivorous fishes fractionate ${ }^{15} \mathrm{~N}$ more strongly than do herbivorous insects (Davis et al. 2012, Bunn et al. 2013), so the TP of LFEs feeding on fish herbivores will be overestimated when the stable isotope approach is used. Therefore, the $1 \mathrm{TP}$ difference between tropical and temperate systems observed here is probably conservative. This effect is illustrated by the high $\delta^{15} \mathrm{~N}$ relative to biofilm of an herbivorous fish, Roman-nosed Goby (Awaous acritosus), collected with LFEs in the tropical streams (Fig. 6). This species of goby had exclusively plant material in its stomach (S. Balcombe, Griffith University, unpublished data), but on average, had $\delta^{15} \mathrm{~N}$ values that were $3.9 \pm 1.0 \%$ greater than those of biofilm, a trophic fractionation $\left(\Delta^{15} N\right)$ at the upper end of the known range (Vanderklift and Ponsard 2003) but identical to independently estimated $\Delta^{15} \mathrm{~N}$ for other herbivorous fishes in the region (Bunn et al. 2013). Therefore, a mix of herbivorous and omnivorous fishes and large crustaceans in the diet of LFEs in the tropics would explain their low TP despite their often large body size.

Other fish species present in tropical northern Australia are omnivorous throughout their lifespan but switch to an almost exclusively herbivorous diet as they age (Davis et al. 2012). The high proportion of omnivory in the tropics probably includes intraguild predation (IGP), i.e., predation by large omnivores (e.g., fishes) on their smaller herbivore competitors (e.g., grazing insects). Strong IGP can lead to shorter FCL as productivity increases because exclusion of small prey species (Takimoto et al. 2012) switches dominant energy pathways from the top left to the bottom right in Fig. 5. Given these differences in proportion of omnivores and herbivores in the fish community across latitudes, an opportunistic predator, such as an eel that feeds on fish prey of a similar size, will sit higher on the food chain in temperate than in tropical systems (Fig. 5).

The relationship between species richness and predator TP also appears across a gradient of lake age, with older, more species-rich lakes having shorter food chains than newly formed lakes (Doi et al. 2012). Latitude significantly affected maximum FCL in those lakes (Doi et al. 2012), but its effects are difficult to disentangle from ecosystem age because older fresh waters tend to occur in the tropics, whereas temperate fresh waters are often formed by more recent glaciation processes. However, the same mechanism of a greater proportion of large-bodied herbivores and omnivores would explain findings from both investigations (i.e., Doi et al. 2012, this study). Teasing out the relative

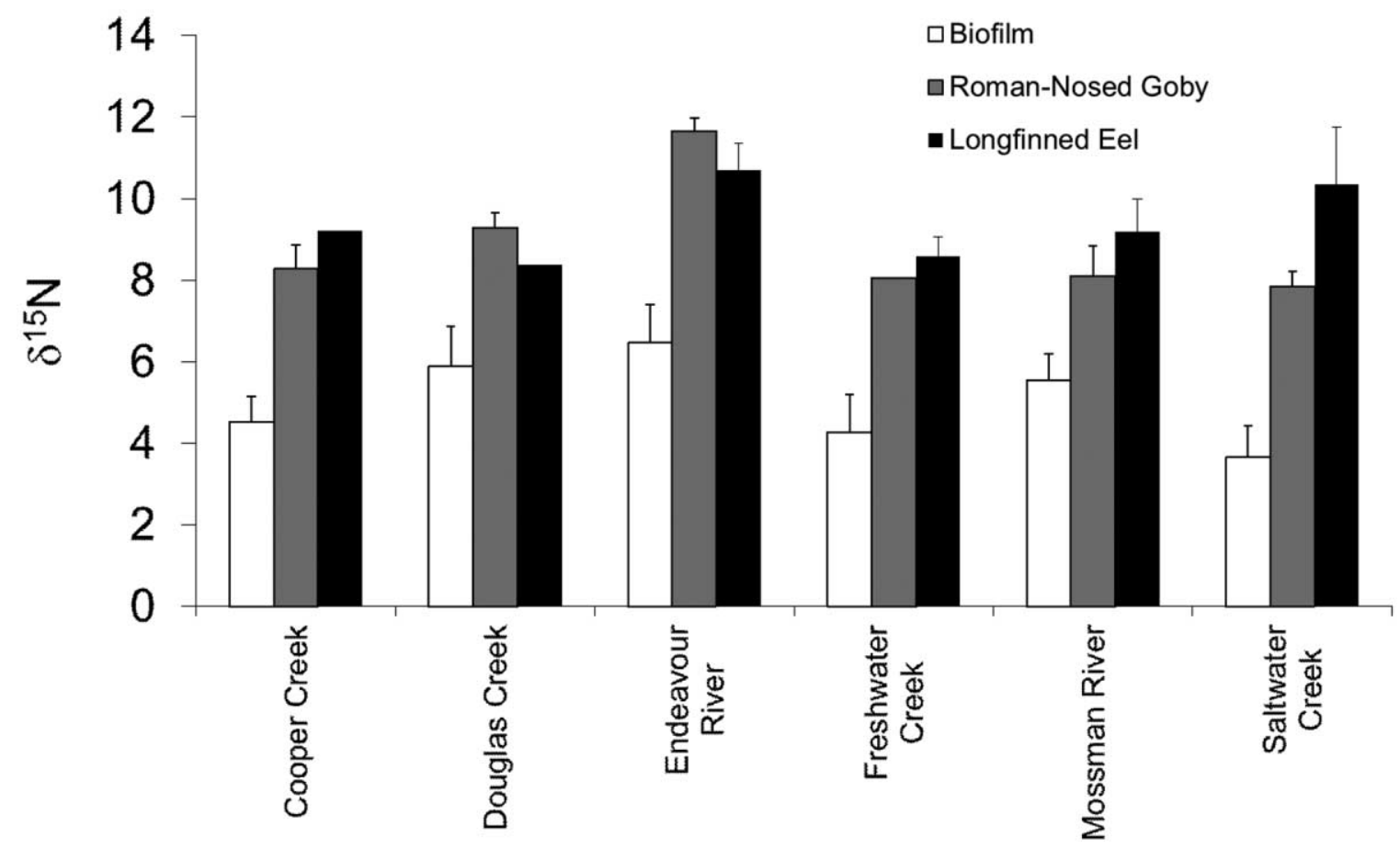

Figure 6. Mean (+1 SD) stable $\delta^{15} \mathrm{~N}$ isotope ratios of biofilm, a representative herbivorous fish (Roman-Nosed Goby) and Longfinned Eels collected simultaneously in tropical streams of northern Queensland, Australia. 
influence of temperature/productivity vs species richness in determining predator TP and maximum FCL will be an important path for future investigations.

A $2^{\text {nd }}$ mechanism whereby tropical fresh waters could support shorter food chains is greater omnivory throughout the food web, e.g., by predatory invertebrates. This explanation does not require a change in the identity of the top predator across the gradient of interest (sensu Post and Takimoto 2007). However, my data suggest that trophic omnivory within the invertebrate food web did not vary among regions because differences in $\delta^{15} \mathrm{~N}$ across regions were apparent only between LFEs and predatory insects and not between predatory insects and herbivorous insects (Fig. 3). Jardine (2014) reported similar body-size vs TP relationships for invertebrates from the 4 regions examined here, but crustaceans that are more common in tropi$\mathrm{cal}$ and subtropical regions had larger body sizes for a given TP compared to insects. Thus, these crustaceans may be a suitable prey item for large LFEs (Pusey et al. 2004) and also account for their low TPs in warm regions.

The $3^{\text {rd }}$ possible mechanism driving variation in FCL is addition or removal of top predators that changes the identity of the apical predator (Post and Takimoto 2007). I did not assess this mechanism. Other predators that feed on eels might exist that could extend the total length of the food chain in the tropics. These species include saltwater crocodiles (Crocodylus porosus) and various piscivorous wading birds, though none of these taxa were common in the relatively small streams examined here, and crocodiles show lower $\delta^{15} \mathrm{~N}$ than would be expected of a predator at the top of a long food chain (Hanson et al. 2015). The role of piscivorous birds in extending FCL is a key area for further investigation (Steinmetz et al. 2003). Moreover, parallel food chains in the tropics that originate with insects and culminate with other large fishes (McHugh et al. 2010, Warfe et al. 2013) also could be prevalent and would yield higher top-predator $\delta^{15} \mathrm{~N}$ than food chains associated with LFEs. Testing for these maximum FCLs would require sampling of all possible predatory fishes, a significant undertaking across such a large geographic range.

Tropical fresh waters contain short, diffuse, and interconnected food webs (Jepsen and Winemiller 2002) and, thus, should exhibit differences in functional attributes when compared to temperate streams. This characteristic has implications for models of ecosystem function that often are used to inform management decisions. Such models include trophic cascades induced by the addition of top predators (Carpenter et al. 1985), changes in patterns of nutrient cycling associated with the addition or removal of species (Taylor et al. 2006), and the likelihood of high contaminant concentrations in top predators that sit at the end of food chains (Kidd et al. 1995). Given the rapid rates of human development in countries with tropical and subtropical climates, the need is pressing to better predict the consequences of agricultural and industrial activities in these regions and to test whether models that were developed in temperate regions will be adequate for the challenge. Fundamental differences in ecosystem properties undoubtedly will lead to variable responses to environmental change.

\section{ACKNOWLEDGEMENTS}

Funding for this project was provided by a Griffith University New Researcher Grant. The author is indebted to Dominic Valdez, Laura Jardine, Jon Marshall, Ryan Woods, Joanne Blessing, Tim Farrell, Brian Fry, David Sternberg, Sophie Bernays, Rob Rolls, Frank Amstatter, David Crook, and Danielle Warfe for field assistance, to Rene Diocares for analyzing samples, and to Danielle Warfe and 2 anonymous referees for comments on an earlier draft.

\section{LITERATURE CITED}

Behmer, S. T., and A. Joern. 2008. Coexisting generalist herbivores occupy unique nutritional feeding niches. Proceedings of the National Academy of Sciences of the United States of America 105:1977-1982.

Bunn, S. E., C. Leigh, and T. D. Jardine. 2013. Diet-tissue fractionation of $\delta \mathrm{N}$ by consumers in streams and rivers. Limnology and Oceanography 58:765-773.

Burness, G. P., J. Diamond, and T. Flannery. 2001. Dinosaurs, dragons, and dwarfs: the evolution of maximal body size. Proceedings of the National Academy of Sciences of the United States of America 98:14518-14523.

Burns, A., and K. F. Walker. 2000. Biofilms as food for decapods (Atyidae, Palaemonidae) in the River Murray, South Australia. Hydrobiologia 437:83-90.

Carpenter, S. R., J. F. Kitchell, and J. R. Hodgson. 1985. Cascading trophic interactions and lake productivity. BioScience 35:634639.

Cohen, J. E., and C. M. Newman. 1991. Community area and food-chain length: theoretical predictions. American Naturalist 138:1542-1554.

Davies, P. M., S. E. Bunn, and S. K. Hamilton. 2008. Primary production in tropical streams and rivers. Pages 23-42 in D. Dudgeon (editor). Tropical stream ecology. Academic Press, London, UK.

Davis, A. M., M. L. Blanchette, B. J. Pusey, T. D. Jardine, and R. G. Pearson. 2012. Gut content and stable isotope analyses provide complementary understanding of ontogenetic dietary shifts and trophic relationships among fishes in a tropical river. Freshwater Biology 57:2156-2172.

Doi, H., M. J. Vander Zanden, and H. Hillebrand. 2012. Shorter food chain length in ancient lakes: evidence from a global synthesis. PLoS ONE 7:e37856.

Duffy, J. E., J. P. Richardson, and K. E. France. 2005. Ecosystem consequences of diversity depend on food chain length in estuarine vegetation. Ecology Letters 8:301-309.

France, R., M. Chandler, and R. Peters. 1998. Mapping trophic continua of benthic foodwebs: body size- $\delta \mathrm{N}$ relationships. Marine Ecology Progress Series 174:301-306.

Froese, R., and D. Pauly (editors). 2012. FishBase. (Available from: www.fishbase.org) 
González-Bergonzoni, I., M. Meerhoff, T. A. Davidson, F. Teixeirade Mello, A. Baattrup-Pedersen, and E. Jeppesen. 2012. Metaanalysis shows a consistent and strong latitudinal pattern in fish omnivory across ecosystems. Ecosystems 15:492-503.

Gooderham, J., and E. Tsyrlin. 2002. The waterbug book. CSIRO Publishing, Melbourne, Australia.

Gross, M. R., R. M. Coleman, and R. M. McDowall. 1988. Aquatic productivity and the evolution of diadromous fish migration. Science 239:1291-1293.

Hairston, N. G., and N. G. Hairston. 1993. Cause-effect relationships in energy flow, trophic structure, and interspecific interactions. American Naturalist 142:379-411.

Hanson, J. O., S. W. Salisbury, H. A. Campbell, R. G. Dwyer, T. D. Jardine, and C. E. Franklin. 2015. Feeding across the food web: the interaction between diet, movement and body size in estuarine crocodiles (Crocodylus porosus). Austral Ecology 40:275-286.

Hoeinghaus, D. J., K. O. Winemiller, and A. A. Agostinho. 2008. Hydrogeomorphology and river impoundment affect foodchain length of diverse Neotropical food webs. Oikos 117:984995.

Ibanez, C., J. Belliard, R. M. Hughes, P. Irz, A. Kamdem-Toham, N. Lamouroux, P. A. Tedesco, and T. Oberdorff. 2009. Convergence of temperate and tropical stream fish assemblages. Ecography 32:658-670.

Jacobsen, D., C. Cressa, J. M. Mathooko, and D. Dudgeon. 2008. Macroinvertebrates: composition, life histories and production. Pages 65-105 in D. Dudgeon (editor). Tropical stream ecology. Elsevier, London, UK.

Jardine, T. D. 2014. Organic matter sources and size-structuring in stream invertebrate food webs across a latitudinal gradient. Freshwater Biology 59:1509-1521.

Jardine, T. D., R. J. Hunt, B. J. Pusey, and S. E. Bunn. 2011. A non-lethal sampling method for stable carbon and nitrogen isotope studies of tropical fishes. Marine and Freshwater Research 62:83-90.

Jennings, S., and K. J. Warr. 2003. Smaller predator-prey body size ratios in longer food chains. Proceedings of the Royal Society of London Series B: Biological Sciences 270:14131417.

Jepsen, D. B., and K. O. Winemiller. 2002. Structure of tropical river food webs revealed by stable isotope ratios. Oikos 96: 46-55.

Kennard, M. J., B. J. Pusey, J. D. Olden, S. J. Mackay, J. L. Stein, and N. Marsh. 2010. Classification of natural flow regimes in Australia to support environmental flow management. Freshwater Biology 55:171-193.

Kidd, K. A., D. W. Schindler, D. C. G. Muir, W. L. Lockhart, and R. H. Hesslein. 1995. High concentrations of toxaphene in fishes from a subarctic lake. Science 269:240-242.

Layman, C. A., K. O. Winemiller, D. A. Arrington, and D. B. Jepsen. 2005. Body size and trophic position in a diverse tropical food web. Ecology 86:2530-2535.

Lewis, Jr, W. M., S. K. Hamilton, M. A. Rodríguez, J. F. I. Saunders, and M. A. Lasi. 2001. Foodweb analysis of the Orinoco floodplain based on production estimates and stable isotope data. Journal of the North American Benthological Society 20:241-254.

Lujan, N. K., D. P. German, and K. O. Winemiller. 2011. Do wood-grazing fishes partition their niche? Morphological and isotopic evidence for trophic segregation in Neotropical Loricariidae. Functional Ecology 25:1327-1338.

McHugh, P. A., A. R. McIntosh, and P. G. Jellyman. 2010. Dual influences of ecosystem size and disturbance on food chain length in streams. Ecology Letters 13:881-890.

McKinney, M. L. 1997. Extinction vulnerability and selectivity: combining ecological and paleontological views. Annual Review of Ecology and Systematics 28:495-516.

Morin, A., W. Lamoureux, and J. Busnarda. 1999. Empirical models predicting primary productivity from chlorophyll $a$ and water temperature for stream periphyton and lake and ocean phytoplankton. Journal of the North American Benthological Society 18:299-307.

Novotny, V., P. Drozd, S. E. Miller, M. Kulfan, M. Janda, Y. Basset, and G. D. Weiblen. 2006. Why are there so many species of herbivorous insects in tropical rainforests? Science 313: $1115-1118$.

Oksanen, L., S. D. Fretwell, J. Arruda, and P. Niemela. 1981. Exploitation ecosystems in gradients of primary productivity. American Naturalist 118:240-261.

Pimm, S. L. 2002. Food webs. University of Chicago Press, Chicago, Illinois.

Post, D. M. 2002. The long and short of food chain length. Trends in Ecology and Evolution 17:269-277.

Post, D. M., M. L. Pace, and N. G. Hairston. 2000. Ecosystem size determines food-chain length in lakes. Nature 405:10471049.

Post, D. M., and G. Takimoto. 2007. Proximate structural mechanisms for variation in food-chain length. Oikos 116:775782.

Power, M. E., M. S. Parker, and W. E. Dietrich. 2008. Seasonal reassembly of a river food web: floods, droughts, and impacts of fish. Ecological Monographs 78:263-282.

Pusey, B., M. Kennard, and A. Arthington. 2004. Freshwater fishes of north-eastern Australia. CSIRO Publishing, Collingwood, Victoria, Australia.

Pusey, B., M. Kennard, D. Burrows, C. Perna, P. Kyne, B. Cook, and J. Hughes. 2011. Freshwater fish. Pages 71-92 in B. Pusey (editor). Aquatic biodiversity in northern Australia: patterns, threats and future. Charles Darwin University Press, Darwin, Australia.

Riede, J. O., U. Brose, B. Ebenman, U. Jacob, R. Thompson, C. R. Townsend, and T. Jonsson. 2011. Stepping in Elton's footprints: a general scaling model for masses and trophic levels across ecosystems. Ecology Letters 14:169-178.

Sabo, J. L., J. C. Finlay, T. Kennedy, and D. M. Post. 2010. The role of discharge variation in scaling of drainage area and food chain length in rivers. Science 330:965-967.

Schoener, T. W. 1974. Resource partitioning in ecological communities. Science 185:27-39.

Schoener, T. W. 1989. Food webs from the small to the large. Ecology 70:1559-1589.

Sergio, F., T. Caro, D. Brown, B. Clucas, J. Hunter, J. Ketchum, K. McHugh, and F. Hiraldo. 2008. Top predators as conservation tools: ecological rationale, assumptions, and efficacy. Annual Review of Ecology, Evolution, and Systematics 39:119.

Shiao, J.-C., W.-N. Tzeng, A. Collins, and Y. Iizuka. 2002. Role of marine larval duration and growth rate of glass eels in determining the distribution of Anguilla reinhardtii and $A$. 
australis on Australian eastern coasts. Marine and Freshwater Research 53:687-695.

Steinmetz, J., S. L. Kohler, and D. A. Soluk. 2003. Birds are overlooked top predators in aquatic food webs. Ecology 84:13241328.

Sullivan, S. M. P., M. C. Watzin, and W. C. Hession. 2006. Influence of stream geomorphic condition on fish communities in Vermont, U.S.A. Freshwater Biology 51:1811-1826.

Takimoto, G., and D. M. Post. 2013. Environmental determinants of food-chain length: a meta-analysis. Ecological Research 28: 675-681.

Takimoto, G., D. M. Post, D. A. Spiller, and R. D. Holt. 2012. Effects of productivity, disturbance, and ecosystem size on foodchain length: insights from a metacommunity model of intraguild predation. Ecological Research 27:481-493.

Taylor, B. W., A. S. Flecker, and R. O. Hall. 2006. Loss of a harvested fish species disrupts carbon flow in a diverse tropical river. Science 313:833-836.

Tunney, T. D., K. S. McCann, N. P. Lester, and B. J. Shuter. 2012. Food web expansion and contraction in response to changing environmental conditions. Nature Communications 3:1105.

Unmack, P. J. 2001. Biogeography of Australian freshwater fishes. Journal of Biogeography 28:1053-1089.

Vander Zanden, M. J., and W. W. Fetzer. 2007. Global patterns of aquatic food chain length. Oikos 116:1378-1388.
Vander Zanden, M. J., and J. B. Rasmussen. 1996. A trophic position model of pelagic food webs: impact on contaminant bioaccumulation in lake trout. Ecological Monographs 66:451477.

Vanderklift, M. A., and S. Ponsard. 2003. Sources of variation in consumer-diet delta N-15 enrichment: a meta-analysis. Oecologia (Berlin) 136:169-182.

Wagner, C. E., P. B. McIntyre, K. S. Buels, D. M. Gilbert, and E. Michel. 2009. Diet predicts intestine length in Lake Tanganyika's cichlid fishes. Functional Ecology 23:1122-1131.

Warfe, D. M., T. D. Jardine, N. E. Pettit, S. K. Hamilton, B. J. Pusey, S. E. Bunn, P. M. Davies, and M. M. Douglas. 2013. Productivity, disturbance and ecosystem size have no influence on food chain length in seasonally connected rivers. PLoS ONE 8: e66240.

Willig, M. R., D. M. Kaufman, and R. D. Stevens. 2003. Latitudinal gradients of biodiversity: pattern, process, scale, and synthesis. Annual Review of Ecology, Evolution, and Systematics 34:273-309.

Winemiller, K. O. 1990. Spatial and temporal variation in tropical fish trophic networks. Ecological Monographs 60:331367.

Woodward, G., and A. G. Hildrew. 2001. Invasion of a stream food web by a new top predator. Journal of Animal Ecology 70:273-288. 